\title{
Equilibrium triple point pressure and pressure-temperature phase diagram of polyethylene
}

\section{Citation for published version (APA):}

Hikosaka, M., Tsukijima, K., Rastogi, S., \& Keller, A. (1992). Equilibrium triple point pressure and pressuretemperature phase diagram of polyethylene. Polymer, 33(12), 2502-2507. https://doi.org/10.1016/00323861(92)91130-T

DOI:

10.1016/0032-3861(92)91130-T

Document status and date:

Published: 01/01/1992

\section{Document Version:}

Publisher's PDF, also known as Version of Record (includes final page, issue and volume numbers)

\section{Please check the document version of this publication:}

- A submitted manuscript is the version of the article upon submission and before peer-review. There can be important differences between the submitted version and the official published version of record. People interested in the research are advised to contact the author for the final version of the publication, or visit the $\mathrm{DOI}$ to the publisher's website.

- The final author version and the galley proof are versions of the publication after peer review.

- The final published version features the final layout of the paper including the volume, issue and page numbers.

Link to publication

\section{General rights}

Copyright and moral rights for the publications made accessible in the public portal are retained by the authors and/or other copyright owners and it is a condition of accessing publications that users recognise and abide by the legal requirements associated with these rights.

- Users may download and print one copy of any publication from the public portal for the purpose of private study or research.

- You may not further distribute the material or use it for any profit-making activity or commercial gain

- You may freely distribute the URL identifying the publication in the public portal.

If the publication is distributed under the terms of Article 25fa of the Dutch Copyright Act, indicated by the "Taverne" license above, please follow below link for the End User Agreement:

www.tue.nl/taverne

Take down policy

If you believe that this document breaches copyright please contact us at:

openaccess@tue.nl

providing details and we will investigate your claim. 


\title{
Equilibrium triple point pressure and pressure-temperature phase diagram of polyethylene*
}

\author{
M. Hikosaka† and K. Tsukijima \\ Department of Materials Science and Engineering, Faculty of Engineering, Yamagata \\ University, Yonezawa, 992 Japan
}

and S. Rastogi

H.H. Wills Physics Laboratory, University of Bristol, Tyndall Avenue, Bristol BS8 1TL, UK (Received 16 May 1991; revised 20 November 1991; accepted 27 February 1992)

\begin{abstract}
The equilibrium triple point and pressure and temperature phase diagram of polyethylene were obtained by in situ optical microscopic and X-ray observations of the melting temperature of hexagonal and orthorhombic isolated extended chain single crystals at high pressure. The melting temperatures of extended chain crystals still showed a $\Delta T$ dependence at high pressure, which has been neglected in previous studies. The triple point pressure and temperature were $0.5 \times 10^{8}-1.5 \times 10^{8} \mathrm{~Pa}$ and $20-30^{\circ} \mathrm{C}$ higher than those previously obtained by the d.t.a. method. These results suggest that lamellar thickness dependence is important even in extended chain crystals to obtain equilibrium thermodynamic physical quantities of polymers.
\end{abstract}

(Keywords: X-ray; polarizing optical microscopy; extended chain single crystals; equilibrium melting temperature; equilibrium triple point; $P-T$ phase diagram

\section{INTRODUCTION}

\section{Pressure-temperature phase diagram}

The pressure-temperature $(P-T)$ phase diagram is basically important in the study of materials, especially in crystallization under high pressure. The $P-T$ phase diagram of polymers has been constructed by the d.t.a. method by Bassett et al. ${ }^{1}$, Yasuniwa et al. ${ }^{2}$ and by one of us $(\mathrm{MH})^{3}$, or through the X-ray method by Yamamoto et al. ${ }^{4}$. Figure $l$ shows the most typical $P-T$ phase diagram obtained for polyethylene (PE) by the d.t.a. method $^{1-3}$.

It has been considered, without detailed experimental evidence, that the melting temperature $\left(T_{\mathrm{m}}\right)$ observed at high pressure of an extended chain crystal (ECC) of a polymer is nearly equal to the equilibrium melting temperature $\left(T_{\mathrm{m}}^{0}\right)$. This is not obvious, because at atmospheric pressure, $T_{\mathrm{m}}$ of an ECC is shown to be $2-3 \mathrm{~K}$ lower than $T_{\mathrm{m}}^{0}$ by Prime and Wunderlich ${ }^{5}$. We recently found that the $T_{\mathrm{m}}$ of isothermally crystallized ECCs of some polymers still depends on the degree of supercooling $\Delta T$ of hexagonal crystals ${ }^{6}$. This suggests that the lamellar thickness of the ECC still depends on $\Delta T$ and that $T_{\mathrm{m}}$ of the ECC must be lower than $T_{\mathrm{m}}^{0}$. The $\Delta T$ dependence of the lamellar thickness is actually confirmed in the case of poly (1,4-trans-butadiene) and polychlorotrifluoroethylene? ${ }^{7}$. In these cases, the $P-T$ phase diagrams obtained by the d.t.a. method are not the equilibrium diagrams for the reason shown below.

* Paper presented at 'Polymer Physics', 3-5 April 1991, Bristol, UK $\uparrow$ To whom correspondence should be addressed

Present address: Department of Physics, Lucknow University, Lucknow-7, India

0032-3861/92/122502-06

(C) 1992 Butterworth-Heinemann Ltd

2502 POLYMER, 1992, Volume 33, Number 12
In the d.t.a. method, the ECC is usually crystallized by slow cooling. The cooling rate is $\sim 1-10^{\circ} \mathrm{C} \mathrm{m^{-1 }}$. In this case, there is a strong possibility that $T_{\mathrm{m}}$ will have a lower value than for a sample of isothermally crystallized ECC at low $\Delta T$, i.e. at high temperature, because the lamellar thickness of slowly cooled ECC must be smaller than that of isothermally crystallized ECC. If so, the $P-T$ phase diagram obtained by the d.t.a. method cannot be regarded as corresponding to equilibrium and it is necessary to construct a correct equilibrium $P-T$ phase diagram by a method other than d.t.a

The best method for this purpose, is direct observation of $T_{\mathrm{m}}$ by optical microscopy $(\mathrm{OM})^{8,9}$. If $T_{\mathrm{m}}$ of isothermally crystallized ECC (at a high pressure) is directly observed by $\mathrm{OM}$ as a function of $\Delta T, T_{\mathrm{m}}^{0}$ can be easily obtained by extrapolating $T_{\mathrm{m}}$ for $\Delta T=0$, where the ECC should be infinitely thick. The equilibrium $P-T$ phase diagram can then be constructed by plotting $T_{\mathrm{m}}^{0}$ as a function of $P$.

The purpose of this study is to construct the equilibrium $P-T$ phase diagram of $P E$ by the above method. In the conventional phase diagram of PE (Figure 1), three phases, liquid, hexagonal and orthorhombic are seen and the triple point is indicated by $Q$. Therefore, in principle, the equilibrium phase diagram will be constructed by finding the triple point $Q$ and the melting curves for infinitely thick hexagonal and orthorhombic crystals.

In this study the phases will be distinguished by the in situ X-ray method and the $T_{\mathrm{m}} \mathrm{s}$ of hexagonal and orthorhombic crystals will be also directly observed by $\mathrm{OM}$ at high pressure by using a newly constructed piston cylinder high pressure system ${ }^{9}$. Here the $T_{\mathrm{m}} \mathrm{s}$ of hexagonal 


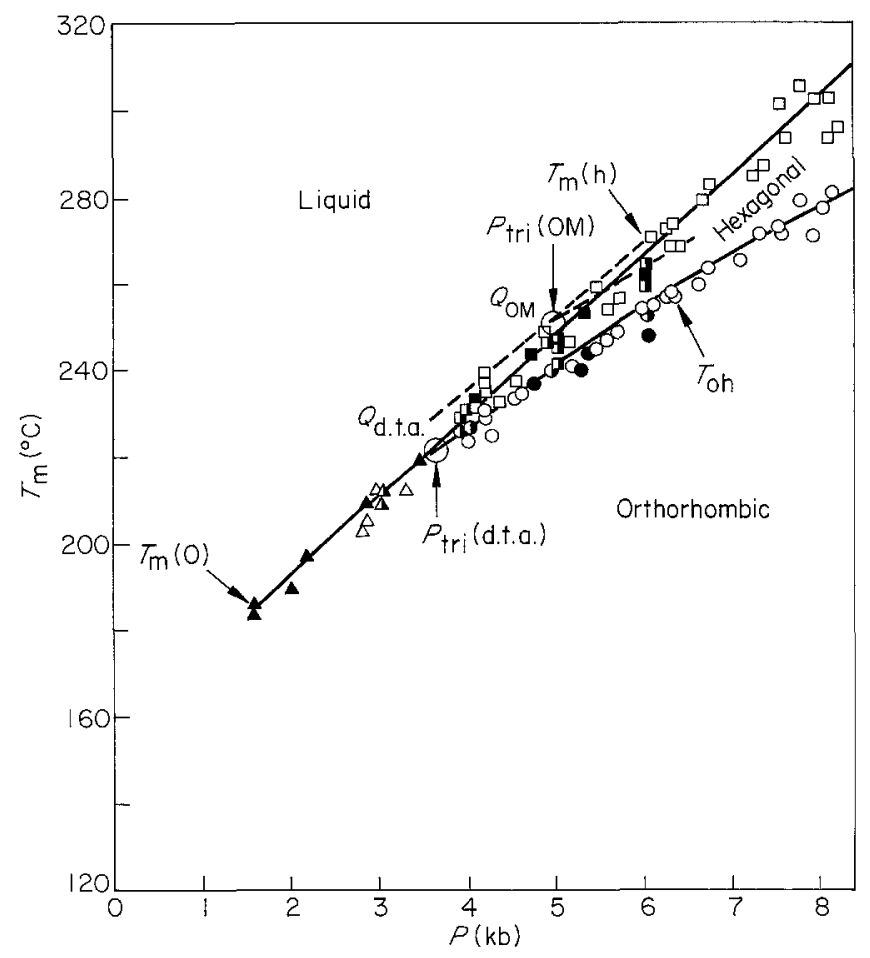

Figure $1 P-T$ phase diagram of PE. $T_{\mathrm{m}}(\mathrm{h})$ (squares) and $T_{\mathrm{m}}(\mathrm{o})$ (triangles) are the melting temperature of hexagonal and orthorhombic crystals and $T_{\text {on }}$ (circles) is the hexagonal-orthohombic transition temperature. $Q$ indicates the triple point. The solid curves indicate melting and phase transition curves obtained by d.t.a. ${ }^{1-3}$. The broken curves indicate equilibrium curves extrapolated from optical microscopic observation in this work. $(\boldsymbol{\square}, \mathbf{O}, \mathbf{\Delta})$ Bassett et al. ${ }^{1} ;(\mathbf{Q}, \mathbf{O}, \mathbf{\Delta})$ Yasuniwa et al. ${ }^{2} ;(\square, O, \triangle)$ Hikosaka et al. ${ }^{3}$

and orthorhombic crystals are denoted by $T_{\mathrm{m}}(\mathrm{h})$ and $T_{\mathrm{m}}(\mathrm{o})$, respectively.

The above procedure results in much higher equilibrium curves for $T_{\mathrm{m}}(\mathrm{h})$ and $T_{\mathrm{m}}(\mathrm{o})$ versus $P$ than those in previous work. The equilibrium triple point pressure $\left(P_{\text {tri }}^{0}\right)$ and temperature $\left(T_{\text {tri }}^{0}\right)$, become correspondingly higher $\left(P_{\mathrm{tri}}^{0}=4 \times 10^{8}-5 \times 10^{8} \mathrm{~Pa}\right.$ and $T_{\mathrm{tri}}^{0}=$ $240-250^{\circ} \mathrm{C}$ ) compared to values obtained previously by d.t.a. $\left(P_{\mathrm{tri}}=3.6 \times 10^{8} \mathrm{~Pa} \text { and } T_{\mathrm{tri}}=230^{\circ} \mathrm{C}\right)^{1-3}$.

\section{Relationship between $\mathrm{P}-\mathrm{T}$ phase diagram and crystallization}

Recently, one of us ( $\mathrm{MH}$ ) proposed a sliding diffusion theory to explain the origin of ECCs and folded chain crystals (FCCs) in polymers ${ }^{10}$. The theory predicts that the polymer chain can slide easily in the mobile haxagonal phase, which will lead to the formation of ECCs. We have recently confirmed these predictions for several polymers ${ }^{7,9}$.

It should be emphasized that, as we have recently shown $n^{9,11}$, the hexagonal phase can exist not only as a thermodynamically stable phase but also as a metastable phase. This is shown schematically in Figure 2, where the $T_{\mathrm{m}}(\mathrm{h})$ line below the triple point $Q$ represents the melting of metastable hexagonal crystals. We have shown previously that ECCs of PE always arise through the mobile hexagonal phase, irrespective of whether this is a stable or metastable phase, by the newly postulated crystallization mechanism of lamellar thickening growth ${ }^{9}$.

It should be noted further that metastable hexagonal crystals transform statistically into thermodynamically stable orthorhombic crystals, as demonstrated by us $^{9}$ recently. This phase transition seems to be an important factor in determining the final lamellar thickness ${ }^{9}$. This arises in view of our recent finding that thickening growth becomes arrested when the metastable hexagonal phase transforms into the stable orthorhombic phase ${ }^{9,11}$. Accordingly, this phase transformation should also be of consequence for the determination of the lamellar thickness of ECCs of PE.

It follows from the above that $P-T$ phase diagrams are essential for the appreciation of crystallization and the resulting crystalline texture of polymers.

\section{EXPERIMENTAL}

\section{Material and apparatus}

Fractionated PE (NBS1483, $\left.M_{\mathrm{w}}=32000\right)$ was isothermally crystallized at a constant high pressure by using a newly constructed piston cylinder high pressure cell. This cell maintains constant pressure during isothermal volume changes. Further, it is fitted with diamond windows, enabling in situ observation of crystallization behaviour and structure by polarizing $\mathrm{OM}$ and the X-ray method ${ }^{8,9}$.

All the experiments were carried out below the equilibrium triple point pressure, i.e. $P<P_{\mathrm{tri}}^{\mathrm{o}}$. The $T$ within the sample cell was calibrated by inserting thermocouples directly within the cell. The experimental error of $T$ was $\pm 2^{\circ} \mathrm{C}$. Pressure within the cell was calculated from the cross-sectional areas of the pistons assuming that piston friction can be neglected. These calculated $P$ values are used throughout this paper. It follows that any experimental error in $P$ is due to neglect of piston friction, and hence must be negative. The magnitude of such an experimental error in $P$ was calibrated by observing the phase transition pressure and lattice spacing of standard materials (benzene, monochlorbenzene and sodium chloride) by using OM

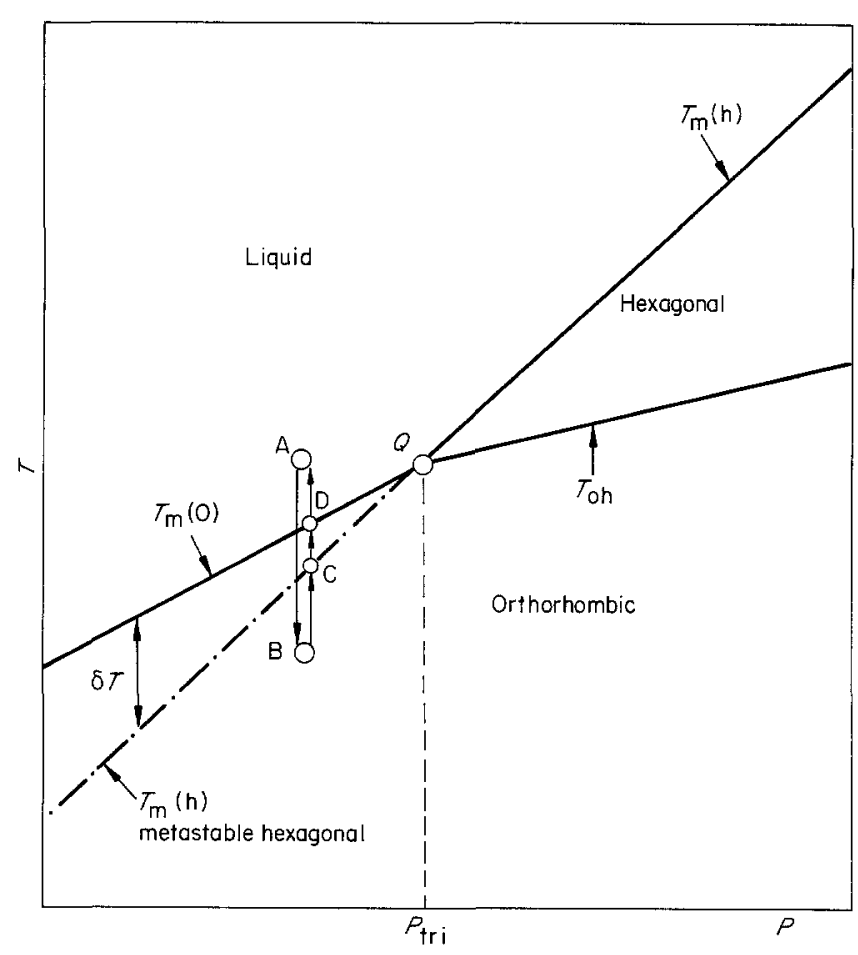

Figure 2 Schematic $P-T$ phase diagram: $Q$ indicates the triple point, $P_{\text {tri }}$ is the triple point pressure and $\delta T$, as shown, is the difference between $T_{\mathrm{m}}(\mathrm{h})$ and $T_{\mathrm{m}}(\mathrm{o})$ 


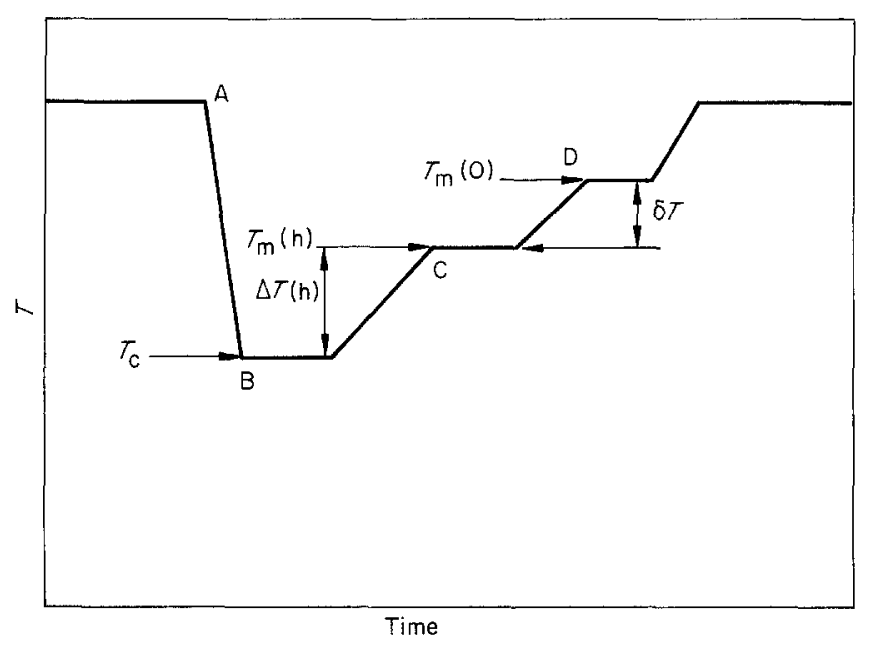

Figure 3 Schematic representation of temperature and time programming used to determine $T_{\mathrm{m}}(\mathrm{h})$ and $T_{\mathrm{m}}(\mathrm{o})$ below the triple point pressure $P_{\text {tri. }}$. Specimen was first melted at A, crystallized at B where hexagonal crystals were crystallized and then transformed into orthorhombic crystals statistically, slowly heated and held at $\mathrm{C}$ where hexagonal crystals began melting $\left[T=T_{\mathrm{m}}(\mathrm{h})\right]$ and heated again and held at $\mathrm{D}$ where orthorhombic crystals began melting $\left[T=T_{\mathrm{m}}(\mathrm{o})\right]$

and the X-ray method. Calibration showed that the error of $P$ is $<-1 \times 10^{8} \mathrm{~Pa}$.

\section{In situ $X$-ray observation}

The distinction between hexagonal and orthorhombic phases was made through in situ X-ray diffraction recording. A specially designed $X$-ray goniometer system was used to obtain Laue spots from extended chain single crystals (ECSCs) of PE (details of this system are to be reported subsequently). An X-ray generator with a rotating anode (Rigaku Denki, RU-3V) was used. Mo $\mathrm{K} \alpha$ radiation, monochromatized by a graphite single crystal or filtered by $\mathrm{Zr}$, was collimated into an area of $0.1 \mathrm{~mm}$ in diameter. Wide angle X-ray scattering (WAXS) patterns were recorded on X-ray films. The camera length was $22-48 \mathrm{~mm}$ and the exposure time was $8-16 \mathrm{~h}$.

Determination of $\mathrm{T}_{m}^{0}$ and $\mathrm{P}_{t r i}^{0}$

$T_{\mathrm{m}}$ was observed experimentally at each pressure as a function of the crystallization temperature $\left(T_{\mathrm{c}}\right)$. Subsequently, $T_{m}^{0}$ was estimated by the Hoffman-Weeks plot method ${ }^{12}$.

$\delta T$ was defined as the difference of $T_{\mathrm{m}}(\mathrm{h})$ and $T_{\mathrm{m}}(\mathrm{o})$ below the triple point, as shown in Figure 2. That is,

$$
\delta T \equiv T_{\mathrm{m}}(\mathrm{h})-T_{\mathrm{m}}(\mathrm{o})
$$

It is obvious that

$$
\delta T=0 \quad \text { at } P=P_{\text {tri }}
$$

Lamellar thickness will become infinite ${ }^{13}$ for $\Delta T=0 \mathrm{~K}$, because the thickness of the critical primary nucleus will become infinite at $\Delta T \rightarrow 0$. Therefore $\delta T_{0}$, defined as $\delta T$ of the infinitely thick lamella, can be estimated from the following relation:

$$
\lim _{\Delta T \rightarrow 0} \delta T=\delta T_{0}
$$

It is obvious that

$$
\delta T_{0}=0 \quad \text { at } P=P_{\mathrm{tri}}^{0}
$$

Consequently $P_{\text {tri }}^{0}$ can be determined by finding $P$ where $\delta T_{0}=0$.

\section{Determination of $T_{m}(h)$ and $\mathrm{T}_{m}(o)$}

Figure 3 shows a schematic diagram of $T$ versus time used to determine $T_{\mathrm{m}}(\mathrm{h})$ and $T_{\mathrm{m}}(\mathrm{o})$. The path $\mathrm{ABCD}$ is also illustrated in Figure 2. Below $P_{\text {tri }}$, PE was melted once (point A) and isothermally crystallized (point B ) into metastable hexagonal crystals. After a certain induction time, some of the crystals transformed into orthorhombic crystals, as confirmed by in situ X-ray diffraction. Then the sample was slowly heated up to temperatures (points $\mathrm{C}$ and $\mathrm{D}$ ) where the hexagonal and orthorhombic crystals began to melt, from which $T_{\mathrm{m}}(\mathrm{h})$ and $T_{\mathrm{m}}(\mathrm{o})$ were determined, respectively.

\section{RESULTS AND DISCUSSION}

$X$-ray evidence that the morphological change is caused by the hexagonal-orthorhombic phase transition

$X$-ray evidence for the hexagonal-orthorhombic transition for crystals showing changes in morphology when viewed by OM is shown in Figures 4 and 5. With such correlation established the hexagonal-orthorhombic transition can then be readily diagnosed by $\mathrm{OM}$ alone. The ability to distinguish hexagonal and orthorhombic crystals by observing optical microscopic morphology only has already been pointed out by Bassett ${ }^{14,15}$.

Edge on crystals appeared as uniformly bright streaks (Figure $4 a$ ) by OM when they were newly formed from the melt. After some induction time $\tau$, they instantaneously (within $0.04 \mathrm{~s}$ ) changed into blotchy streaks (Figure $5 a)^{14,15}$. The value of $\tau$ varied from a few minutes to a
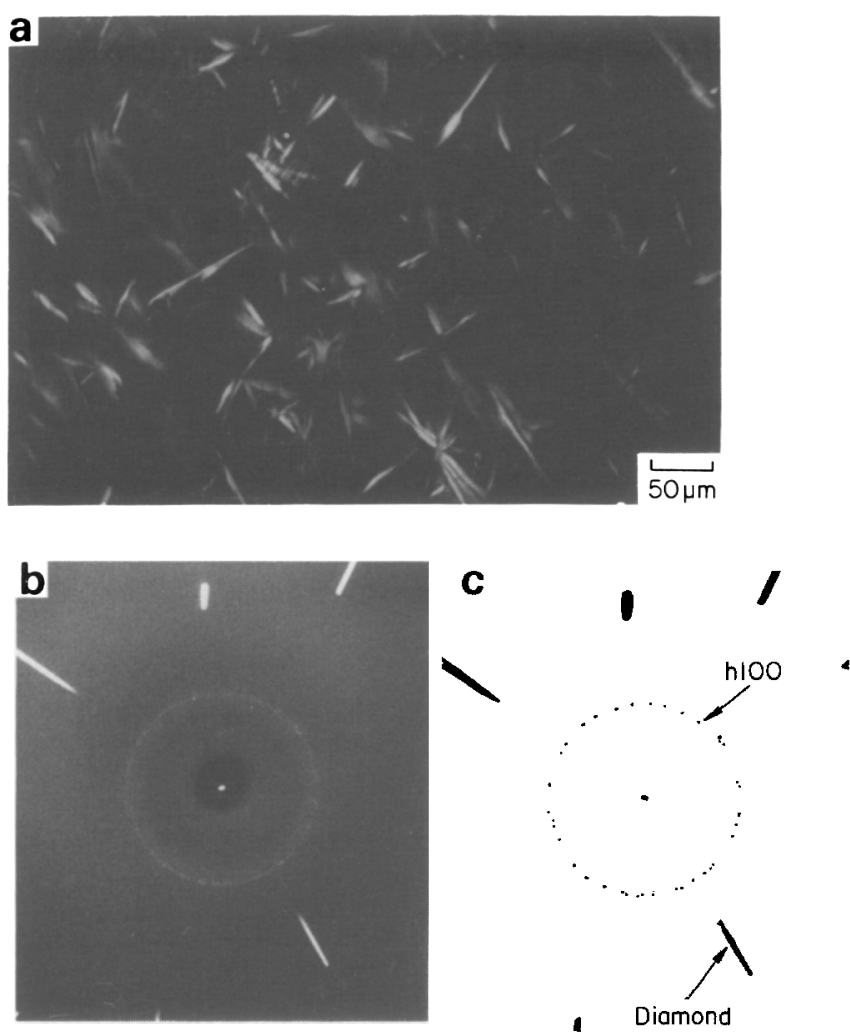

Figure 4 Correspondence of (a) morphology observed by $\mathrm{OM}$ showing uniformly bright streak shaped crystals and (b) WAXS pattern from the same crystals shown in (a) showing spotty hexagonal 100 reflections. (c) Sketch of (b). $P=4 \times 10^{8} \mathrm{~Pa}$ and $\Delta T=3^{\circ} \mathrm{C}$ 

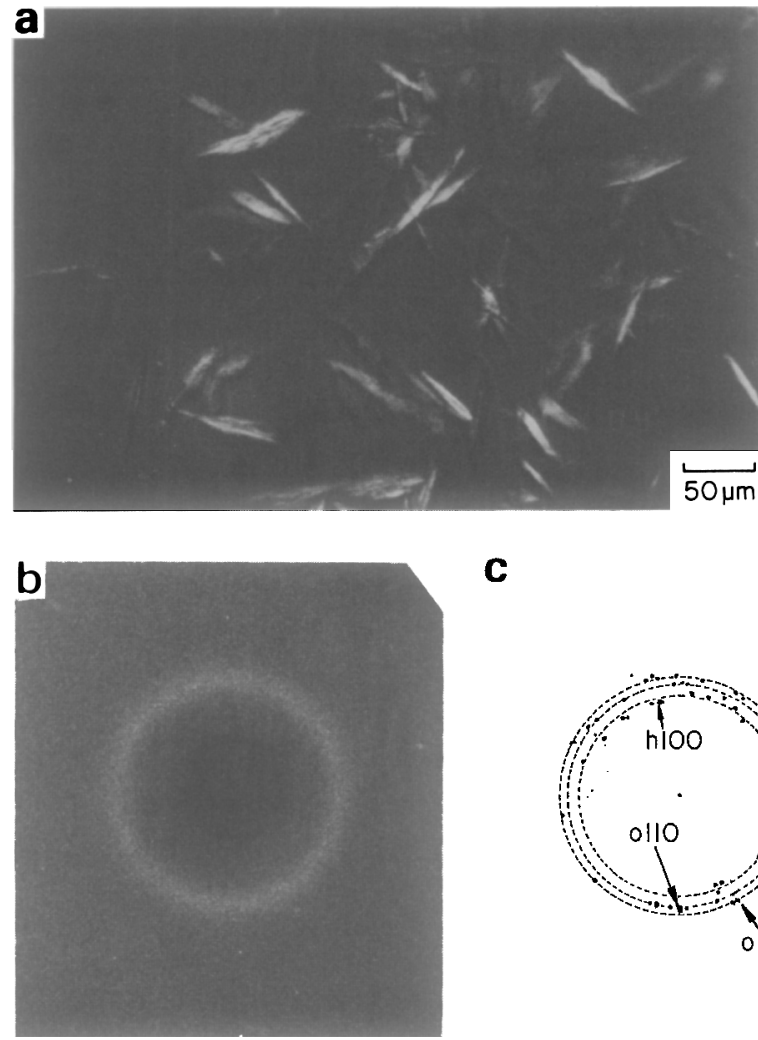

C

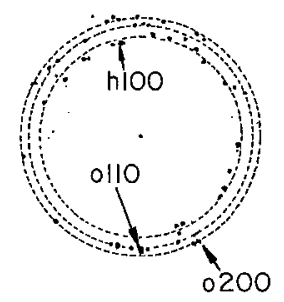

Figure 5 Correspondence of (a) morphology observed by OM showing distorted blotchy streak shaped crystals and (b) WAXS patterns from the same crystals shown in (a) demonstrating coexistence of spotty hexagonal 100 and orthorhombic 110 and 200 refiections. (c) Sketch of (b). $P=3 \times 10^{8} \mathrm{~Pa}$ and $\Delta T=4^{\circ} \mathrm{C}$

few tens of hours, depending on $\Delta T$. X-ray patterns of the former showed spotty hexagonal 100 reflections (lattice spacing $d=4.30 \pm 0.1 \AA$ ), while that of the latter showed spotty orthorhombic 110 and 200 reflections ( $d=4.0 \pm 0.1$ and $3.8 \pm 0.1 \AA$, respectively) (Figures $4 b$ and $c$ and $5 b$ and $c$ ). This demonstrates that the morphological change corresponds to a hexagonalorthorhombic phase transition. The spotty reflections also indicate that the crystals are ECSCs. Thus it is concluded that the hexagonal-orthorhombic phase transition can be directly detected from the morphological change observed by OM and that the hexagonal crystals can be readily distinguished from orthorhombic crystals by the differences in morphology as detected by OM.

\section{Determination of $\mathrm{T}_{m}^{0}(h)$}

Figure 6 is a plot of $T_{m}$ versus $T_{\mathrm{c}}$ at $5 \times 10^{8} \mathrm{~Pa}$. This shows that $T_{\mathrm{ra}}(\mathrm{h})$ of isothermally crystallized isolated ECSCs increased linearly with decrease in $\Delta T$ (i.e. increase in $T_{\mathrm{c}}$ ). This suggests that the lamellar thickness $l$ increases with decrease in $\Delta T$, which is confirmed by Figure 7. Figure 7 shows a plot of $l$ of isolated ECSCs observed by TEM ${ }^{16}$. Therefore it may be assumed that $l$ tends to infinity when $\Delta T$ approaches zero. It should be noted that the lamellae do not thicken during the $T_{\mathrm{m}}$ determination, because the lamellar thickening growth rate decreases significantly ${ }^{17}$ with decrease in $\Delta T$. Combining these results allows the Hoffman-Weeks plot method $^{12}$ to be applied to Figure 6 to determine the equilibrium melting temperature $T_{\mathrm{m}}^{0}(\mathrm{~h})$.

The melting temperature of slowly cooled crystals, $T_{\mathrm{m}}(\mathrm{h})$ (slow cool.), with a cooling rate of $\sim 1-2^{\circ} \mathrm{C} \mathrm{\textrm {min } ^ { - 1 }}$ (the same as in the d.t.a. method ${ }^{1-3}$ ) was also observed by the same step by step heating procedure as shown in Figure 3. $T_{\mathrm{m}}(\mathrm{h})$ (slow cool.) was $2-3 \mathrm{~K}$ lower than $T_{\mathrm{m}}^{0}(\mathrm{~h})$, i.e.

$$
T_{\mathrm{m}}^{0}(\mathrm{~h})=T_{\mathrm{m}}(\mathrm{h})(\text { slow cool. })+(2-3)
$$

and is shown by a dotted line in Figure 6. Equation (5) shows that the $P-T$ phase diagram obtained on the slowly cooled crystals does not correspond to the equilibrium diagram. For an equilibrium phase diagram we need to extrapolate to $T_{\mathrm{m}}^{0}$ values from the $T_{\mathrm{m}}(\mathrm{h})$ values of isothermally crystallized ECSCs by using OM. This result is similar to Prime and Wunderlich's values

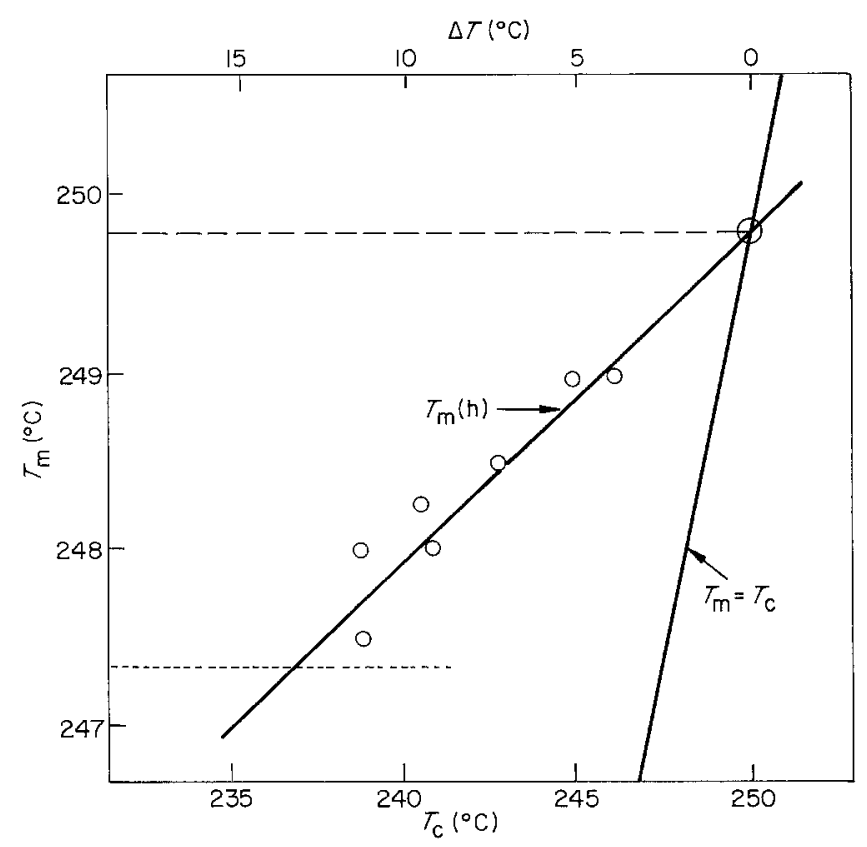

Figure $6 T_{\mathrm{m}}(\mathrm{h})$ versus $T_{c}$ (i.e. $\Delta T$ ). $P=5 \times 10^{8} \mathrm{~Pa}$. Open circles indicate $T_{\mathrm{m}}(\mathrm{h})$ of isothermally crystallized crystals. Dotted line indicates $T_{\mathrm{m}}(\mathrm{h})$ of slowly cooled crystals, $T_{\mathrm{m}}(\mathrm{h})$ ( slow cool.). Broken line indicates $T_{\mathrm{m}}^{\mathrm{o}}$

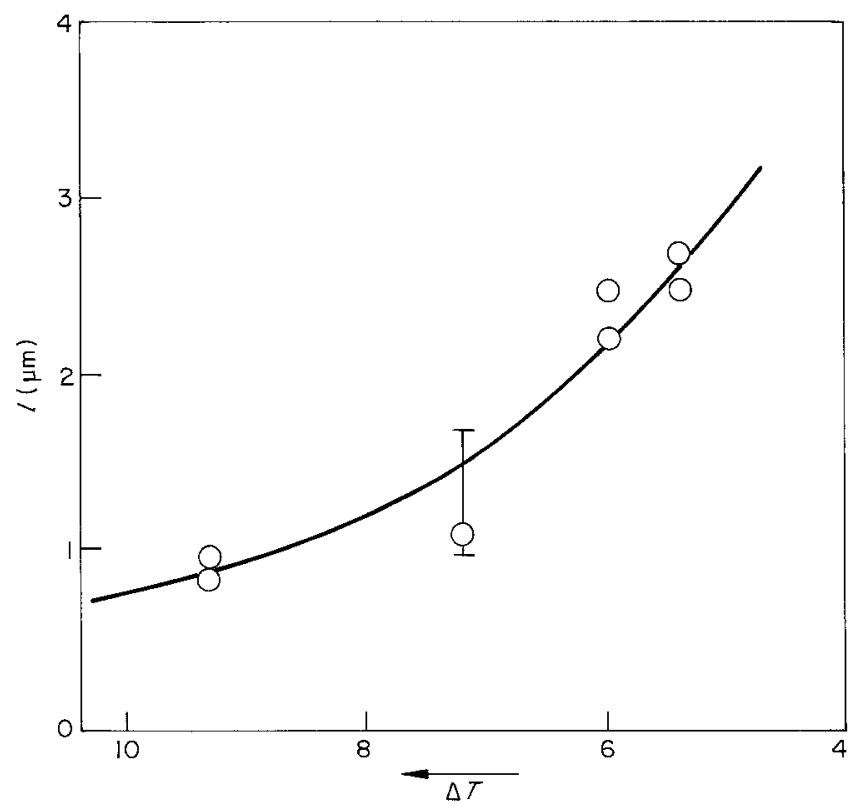

Figure 7 Plot of lamellar thickness $/$ against $\Delta T . P=4.5 \pm 0.5 \times 10^{8} \mathrm{~Pa}$ 

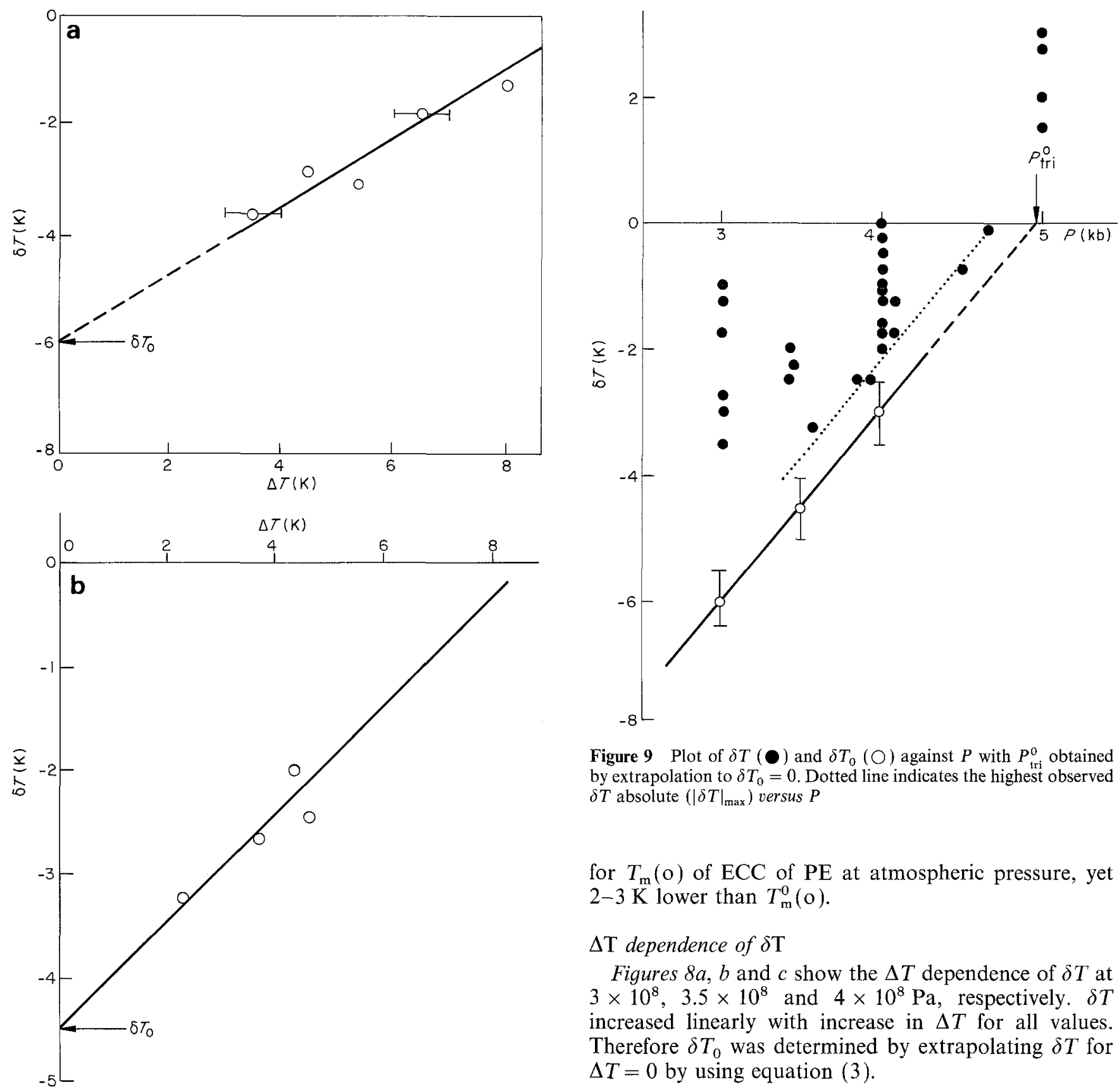

Figure 9 Plot of $\delta T(\bullet)$ and $\delta T_{0}(O)$ against $P$ with $P_{\text {tri }}^{0}$ obtained by extrapolation to $\delta T_{0}=0$. Dotted line indicates the highest observed $\delta T$ absolute $\left(|\delta T|_{\max }\right)$ versus $P$

for $T_{\mathrm{m}}(\mathrm{o})$ of ECC of PE at atmospheric pressure, yet $2-3 \mathrm{~K}$ lower than $T_{\mathrm{m}}^{0}(\mathrm{o})$.

\section{$\Delta \mathrm{T}$ dependence of $\delta \mathrm{T}$}

Figures $8 a, b$ and $c$ show the $\Delta T$ dependence of $\delta T$ at $3 \times 10^{8}, 3.5 \times 10^{8}$ and $4 \times 10^{8} \mathrm{~Pa}$, respectively. $\delta T$ increased linearly with increase in $\Delta T$ for all values. Therefore $\delta T_{0}$ was determined by extrapolating $\delta T$ for $\Delta T=0$ by using equation (3).

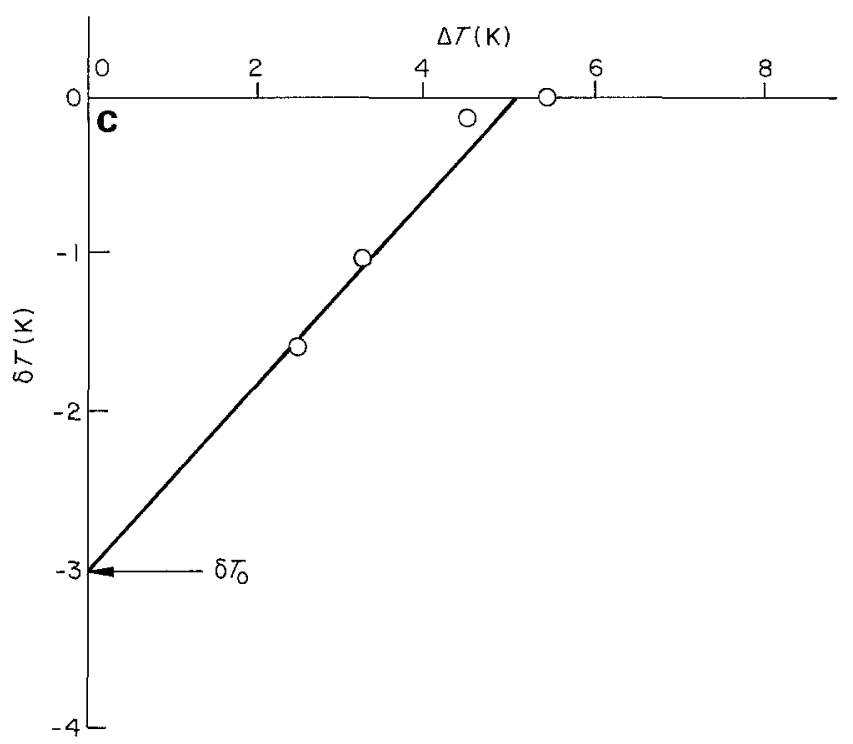

Figure $8 \Delta T$ dependence of $\delta T . P=$ (a) $3 \times 10^{8}$, (b) $3.5 \times 10^{8}$ and (c) $4 \times 10^{8} \mathrm{~Pa}$. $\delta T_{0}$ indicates the extrapolated value for $\Delta T=0$
Determination of $\mathrm{P}_{t r i}^{0}$ and $\mathrm{T}_{\text {tri }}^{0}$

Figure 9 is a plot of $\delta T_{0}$ versus $P$ obtained from the results in Figure 8. It shows that $\delta T_{0}$ also increases linearly with $P . P_{\text {tri }}^{0}$ can now be determined from Figure 9 as the $P$ where $\delta T_{0}$ becomes $0^{\circ} \mathrm{C}$, as follows from equation (4). Figure 9 gives the result that $P_{\text {tri }}^{0}$ is $5 \times 10^{8} \mathrm{~Pa}$. Considering the experimental error in $P$ (as above, $\leqslant-1 \times 10^{8} \mathrm{~Pa}$ ) we have

$$
P_{\text {tri }}^{0}=4 \times 10^{8}-5 \times 10^{8} \mathrm{~Pa}
$$

It should be noted that

$$
T_{\mathrm{tri}}^{\mathrm{o}}=T_{\mathrm{m}}^{0}(\mathrm{~h}) \quad \text { at } P=P_{\mathrm{tri}}^{0}
$$

Therefore, the equilibrium triple point $Q$ must lie along the $T_{\mathrm{m}}^{0}$ versus $P$ curve between $P=4 \times 10^{8} \mathrm{~Pa}$ and $5 \times 10^{8} \mathrm{~Pa}$.

A combination of equation (5) and the melting curve of $T_{\mathrm{m}}$ (h) (d.t.a.) in Figure 1 gives

$$
\begin{array}{r}
T_{\mathrm{m}}^{0}(\mathrm{~h})=240^{\circ} \mathrm{C} \text { for } 4 \times 10^{8} \mathrm{~Pa} \\
\text { and } 250^{\circ} \mathrm{C} \text { for } 5 \times 10^{8} \mathrm{~Pa}
\end{array}
$$


Combining equations (6), (7) and (8) leads to the final conclusion that the equilibrium triple point $Q$ lying along the $T_{\mathrm{m}}^{0}(\mathrm{~h})$ versus $P$ curve is in the range

$$
\left(P_{\text {tri }}^{0}, T_{\text {tri }}^{0}\right)=\left(4 \times 10^{8} \mathrm{~Pa}, 240^{\circ} \mathrm{C}\right)-\left(5 \times 10^{8} \mathrm{~Pa}, 250^{\circ} \mathrm{C}\right)
$$

This is now inserted in Figure 1 (denoted by $Q_{\mathrm{OM}}$ for $\left.P_{\text {tri }}^{0}=5 \times 10^{8} \mathrm{~Pa}\right)$. Thus the new values for $P_{\text {tri }}^{0}$ and $T_{\text {tri }}^{0}$ are $\sim 0.4 \times 10^{8}-1.4 \times 10^{8} \mathrm{~Pa}$ and $20-30^{\circ} \mathrm{C}$ higher than the $P_{\mathrm{tri}}^{0}=3.6 \times 10^{8} \mathrm{~Pa}$ and $T_{\mathrm{tri}}^{0}=220^{\circ} \mathrm{C}$ obtained previously by the d.t.a. method ${ }^{1-3}$. This shows that the effect of $l$ is an important factor in the determination of $P-T$ phase diagrams.

Figure 9 contains all the values of $\delta T$ determined as a function of $\Delta T$ together with the extrapolated $\delta T_{0}$. This shows that $\delta T$ covers a wide range at each pressure, corresponding to the $\Delta T$ dependence of $\delta T$ shown in Figure 8. Thicker lamellae give larger $\delta T$ values (in absolute terms). The highest observed $\delta T$ absolute $\left(|\delta T|_{\max }\right)$ versus $P$ plot displayed a linear relation, shown by a dotted line in Figure 9. The line crosses the horizontal axis at $P=4.7 \times 10^{8} \mathrm{~Pa}$, which can be considered to give an underestimated $P_{\text {tri }}^{o}$.

$$
P_{\text {tri }}^{0}>3.7 \times 10^{8}-4.7 \times 10^{8} \mathrm{~Pa}
$$

where the error in $P=-1 \times 10^{8} \mathrm{~Pa}$. This well supports the above conclusion [equation (6)].

\section{Comparison with previous results by d.t.a.}

When PE was crystallized under conditions similar to those used for the d.t.a. method, i.e. by slow cooling, $\delta T$ showed a much smaller value (absolute) than $\delta T_{0}$; for example, $\delta T=-0.5^{\circ} \mathrm{C}$ at $P=3.5 \times 10^{8} \mathrm{~Pa}$ and $\delta T=0^{\circ} \mathrm{C}$ at $4 \times 10^{8} \mathrm{~Pa}$. This suggests that (considering an experimental error of $-1 \times 10^{8} \mathrm{~Pa}$ ),

$$
P_{\text {tri }}=3 \times 10^{8}-4 \times 10^{8} \mathrm{~Pa}
$$

This agrees, within experimental error, with the results obtained by the d.t.a. method ${ }^{1-3}$

$$
\left.P_{\text {tri }} \text { (d.t.a. }\right)=3.5 \times 10^{8}-3.6 \times 10^{8} \mathrm{~Pa}
$$

This indicates that the two different experimental methods, OM and d.t.a., can be compared within their experimental errors. We therefore consider the final results from equation (9) as reliable.

\section{Equilibrium $\mathrm{P}-\mathrm{T}$ phase diagram}

A combination of the above results for $T_{\mathrm{m}}^{0}$ and $Q_{\mathrm{OM}}$ enables the equilibrium $P-T$ phase diagram to be constructed. This is drawn as the broken curve in Figure 1 , here taken for the case that $P_{\mathrm{tri}}^{0}=5 \times 10^{8} \mathrm{~Pa}$.

\section{CONCLUSIONS}

1. It was shown by direct $\mathrm{X}$-ray diffraction evidence that the morphological change, which can be observed in ECCs of PE by polarized OM, corresponds to a hexagonal-orthorhombic phase transition, as proposed by Bassett ${ }^{14,15}$.
2. The equilibrium melting temperature of ECC hexagonal crystals $\left[T_{\mathrm{m}}^{0}(\mathrm{~h})\right]$ of $\mathrm{PE}$ at high pressure was determined by means of the Hoffman-Weeks plot. $T_{\mathrm{m}}^{0}(\mathrm{~h})$ is $\sim 2-3^{\circ} \mathrm{C}$ higher than $T_{\mathrm{m}}(\mathrm{h})$ of slow cooled ECC crystallized with the same cooling rate as used in the d.t.a. method.

3. The equilibrium triple point $Q$ was determined. It was found to lie along the $T_{\mathrm{m}}^{0}(\mathrm{~h})$ curve within the range of $P=4 \times 10^{8}-5 \times 10^{8} \mathrm{~Pa}$. We now define the location of the triple point by the interval.

$$
\left(P_{\mathrm{tri}}^{0}, T_{\mathrm{tri}}^{0}\right)=\left(4 \times 10^{8} \mathrm{~Pa}, 240^{\circ} \mathrm{C}\right)-\left(5 \times 10^{8}, 250^{\circ} \mathrm{C}\right)
$$

These values are $0.4 \times 10^{8}-1.4 \times 10^{8}$ and $20-30^{\circ} \mathrm{C}$ higher than the $P_{\text {tri }}\left(=3.6 \times 10^{8} \mathrm{~Pa}\right)$ and $T_{\text {tri }}$ $\left(=220^{\circ} \mathrm{C}\right.$ ) obtained previously by the d.t.a. method.

4. A revised equilibrium $P-T$ phase diagram is constructed by combining the results for $T_{m}^{0}(h)$ and the equilibrium triple point $Q$.

\section{ACKNOWLEDGEMENTS}

Two of the authors ( $\mathrm{MH}$ and $\mathrm{KT}$ ) thank Professor H. Ohigashi of Yamagata University for his helpful discussions and also $\mathrm{Mr} \mathrm{H}$. Ota of Yamagata University for his help in the observations on $T_{\mathrm{m}}$. The authors also thank $\mathrm{Mr} \mathrm{T}$. Komazawa and $\mathrm{Mr} \mathrm{A}$. Kurosaki of Nippon Petrochemicals Co. Ltd, for their help in printing X-ray photographs. This work is partly supported by a Grant-in-Aid for Scientific Research from the Ministry of Education and benefitted from earlier support by the Science and Engineering Research Council (London) during the initial stages.

\section{REFERENCES}

1 Bassett, D. C., Block, S. and Piermarini, G. J. J. Appl. Phys $1974,45,4146$

2 Yasuniwa, M., Enoshita, R. and Takemura, T. Jpn J. Appl. Phys. 1976, 15, 1421

3 Hikosaka, M., Minomura, S. and Seto, T. Jpn J. Appl. Phys. $1980,19,1763$

4 Yamamoto, T., Miyaji, H. and Asai, K. Jpn J. Appl. Phys. 1977 16, 1891

5 Prime, R. B. and Wunderlich, B. J. Polym. Sci. A2 1969, 7, 2073

6 Hikosaka, M., Tsukijima, K., Rastogi, S., Keller, A., Kawabata, H. and Komazawa, T. Phys. Soc. Jpn Prepr. 1991, 46(3), 491

7 Hikosaka, M., Kasahara, T., Rastogi, S., Keller, A., Kawabata H. and Komazawa, T. Europhys. Conf. Abst. 1989, 12D, 76

8 Hikosaka, M. and Seto, T. Jpn J. Appl. Phys. 1982, 21, L332; 1984, 23, 956

9 Hikosaka, M., Rastogi, S., Keller, A. and Kawabata, H. J. Macromol. Sci. Phys. 1992, B31, 87

10 Hikosaka, M. Polymer 1987, 28, 1257; 1990, 31, 458

11 Rastogi, S., Hikosaka, M., Kawabata, H. and Keller, A. Macromolecules 1991, 24, 6384

12 Hoffman, J. D. and Weeks, J. J. J. Res. Natl Bur. Std. 1962 , 66A, 13

13 Lauritzen Jr, J. I. and Hoffman, J. D. J. Res. Natl Bur. Std. $1960,64 A, 73$

14 Bassett, D. C. 'Principles of Polymer Morphology', Cambridge University Press, London, 1981, p. 179

15 Bassett, D. C., Block, S. and Piermarini, G. J. J. Appl. Phys. $1974,45,4146$

16 Tsukijima, K., Hikosaka, M., Rastogi, S. and Keller, A. Polym. Prepr. Jpn 1991, 40(11), 4241

17 Hikosaka, M., Kasahara, T., Ichijyo, T., Rastogi, S., Kawabata, H. and Keller, A. Polymer submitted 